\title{
VIOLENCE AND DEATH: THEIR INTERPRETATION BY K. A. PORTER AND EUDORA WELTY
}

\author{
Anna Stegh Camati \\ Universidade Federal do Paraná
}

\begin{abstract}
This study aims to elucidate the reasons for the prevalence of violence in Southern fiction. While $\mathrm{K}$. A. Porter focuses violence as being a characteristic trait of the Southern temper, which can be traced back to the frontier days, Eudora Welty presents variations on the theme of spiritual isolation in her short-stories, which is connected with the conflicting world views of the forties: the confusion of values generated by the discrepancy existing between the ideal Southern society and the real world of the South results in violence. Similar tensions to those of the American South are evoked by K. A. Porter in her Mexican stories. The different connotations of death, both symbolic and real, are also analysed in this study, showing that the recurrence of the death motif has to do with the Southerner's metaphysical preoccupations.
\end{abstract}

\section{INTRODUCTION}

Acts of violence abound in K. A. Porter's and Eudora Welty's fiction, illuminating a world of continual spiritual warfare. According to W. J. Cash in The Mind of the South,' the reasons for the prevalence of violence in Southern temper can be traced back to the frontier days and to the expansion of the plantation empire, when the rough backcountry farmer acquired immense wealth and power by means of the institution of slavery. The priviledge of absolute power within his feudal estate, mixed with ideas of superiority in relation to the Negro, developed in the Southerner an un limited pride, which tended to generate cruelty and violent attitudes. Every prosperous Southerner boasted that "he would knock hell out

I See CASH, W. J. The Mind of the South. Harmondsworth, Penzuin, 1971. p. 25-118.

Letras, Curitiba (32) $39-59-1983$ - UFPR 
of whoever dared to cross him."' Such men, Cash says, "were bound to come often into conflict. And being what they were - simple, direct, and immensely personal - and their world being what it was - conflict with them could only mean immediate physical clashing, could only mean fisticuffs, the gouging ring, and knife and gun play."

Violence as social record is explored by $\mathrm{K}$. A. Porter in her stories about the Old South. In Old Mortality she recounts an episode in which Amy flirts at a masked ball with her for. mer suitor Raymond. This incident provoked outrage in her brother Harry, who shot at the man even before Gabriel could challenge him for a duel.

After the Civil War, the Reconstruction years also stimulated violence in the South. Since the Radicals set out upon a definite policy of punishing the states of the Confederacy, they protected the Negroes to accomplish their design, which started the conflict between the races which extends to our time. This generated more violence, such as the spread of terror of secret organizations like the Ku Klux Klan.

After World War I, some Southern writers attempted to affirm the concept of a Southern culture based on an agrarian society, drawing the picture of a culture that never really existed. The volume I'll Take my Stand,' which came out in 1930 and which is a statement of the philosophy of the socalled Southern Agrarians, is an attempt to affirm a myth that was already dying, as well as to reinforce the ruling faith of the past so as to mold and control the present culture.

At the same time that the Agrarians were reasserting the ethos of the dead past of the South, the frustrations and privations, material, intellectual and spiritual, that really existed for most people in the South were being affirmed by a generation of writers working apart from the Agrarians, who tried to uncover the provincial and regressive aspects of Southern life. To Southern people of lower and middle classes, the world that writers like Faulkner recreated seemed more real than that of the Agrarians.

The generation of writers after the Agrarians and Faulk. ner was thus trapped by an intellectual dualism that did not seem easy to reconcilie. The clash between the ideal Southern society and the real world of the South constituted the centre of interest in the work of the generation of writers of the 40's, who were entrusted to reconcile the disparate claims of these two traditions, which were, in fact, irreconcilable. These writers were confronted with an unenlightened culture, a life of near poverty, and an external world of violence and threate-

2 CASH. p. 63

3 CASH. D. 63.

4 Bee RANBOM, J. C., ed. I'll Take my stand. New York, Harpers, 1982. 
ning. Furthermore, the Great Depression made poverty and marginal existence of much of the Southern lower classes more obvious. The result of all these adverse circumstances was a retreat of the Southern writers, not back to the South or the Southern culture, but back into the individual in his most radically individual mode of existence, as a person alone in an alien land.

The theme of spiritual isolation which can be detected in most of Eudora Welty's stories is certainly connected with the conflicting world views of the 40 's; she not only portrays the feeling of instability and the lack of purpose in the individual's life, but also adverts that moral and spiritual violence, which are the natural consequences of a world of opposing values, leads up to complete destruction of either body or soul.

Eudora Welty frequently fuses violence and the grotesque, since violence can be reinforced by the grotesque situation. However, violence in her stories is never gratuitous or an end in itself; it is the violent situation that best reveals the essence of man. In an incongruous world of harsh discontinuities, violence speaks to us about the most disconcerting realities.

In the present study, I am going to demonstrate that although K. A. Porter and Eudora Welty specialize in folkways, codes of be haviour and social/cultural peculiarities of a particular sub-region, they transcend their region so that the American South or Mexico become microcosms of the world.

In the first part, two stories by $K$. A. Porter will be focused, Maria Concepción (1922) and Hacienda (1934), which were written respectively at the beginning and the end of her Mexican Period, which extends from 1920 to 1931. Similar tensions to those of the American South are evoked in these stories, since the author traces an ironic contrast between appearance and reality. When she first came to Mexico, she was hopeful that the Revolution would reverse centuries of political and economic oppression, rescuing the natives from the degrading hacienda system, which is in many ways no better than slavery.

In the short novel Hacienda, K. A. Porter records her total disenchantment with the Mexican Revolution, creating a "death-centered tragic world", a corrupted world of violence which brutalizes the peons, who are seen as victims of the landowners' greed. While in Maria Concepción she acknowledges her hope in a primitive world with its own order, mora-

5 Sec WaLsH. T. F. Xochitl: Katherine Anne Porter's Changing Goddess. American Literatura, 52 (2): 183, 1980. 
lity and ethic, in Hacienda she expresses her aversion towards the encroachment of Western society and religion, which tend to destroy the Mexican Indian culture, since the white man is not interested in the integration of the Indian into his world, but concerned oniy with his exploitation.

Although K.A. Porter says that she writes about Mexico because it is her "familiar country"," she is not so sentimentally involved with it as she is with her native American South; therefore her insight into the Mexican culture is critical, free from the nostalgic touches which are noticeable in her stories about the old South, in which despite the fact that she attempts to destroy the old myth, we can clearly see that she is still caught up in it.

In the second part of this study, three stories by Eudora Welty will be analyzed: Curtain of Green, Clytie and Asphodel. Evidence will be given that the author has no preoccupation with tradition; while Curtain of Green is a variation on the universal theme of the paradoxical nature of life, Clytie and Asphodel are Southern stories which have a parabolic function, since she presents elements in them that subvert and undermine the Southern myths.

Not only the implications of violence will be discussed in this paper, but also the different connotations of death, both symbolic and real, will be disclosed. The fact that in both writers death is a recurrent motif leads to the conclusion that this has to do with the Southern temper. In his analysis of the decisive identifying characteristics of Southern fiction F. Hoffmann quotes Robert B. Heilman's important statement which presents these distinguisining features: "The Southern temper is marked by the coincidence of a sense of the concrete, a sense of the elemental, a sense of the ornamental, a sense of the representative, and a sense of totality." The 'sense of the elemental' Hoffmann associates with "the Southerner's preocupation with first and last things."

\section{KATHERINE ANN PORTER}

1.1 The Primitive Order: Death and Resurrection in Maria Concepción.

This story is told from the point of view of a Mexican Indian woman who murders her husband's mistress and then takes his child by that woman as her own, after having lost

6 See PORTER. K. A. Why I Write About Mexico. In: The Collected Essays and Occasional Writings of K. A. Parter. Nex York. Dell,1973. D. 355.

7 See HOFFMANN. F. J. The Art of Southern Fietion: a Study of Some Modern Navelists. Carbondale. Sauthern Illinois University Press. 1968. p. 4. 
hers at birth. George Hendrick claims that the central theme in Maria Concepción is "the strength of life over defeated death", 8 which is implied in the name of the pulque shop called "Death and Resurrection", where Juan celebrates his escape from death" and the birth of his son by Maria Rosa.

Although Maria Concepción considered herself a "good Christian"," and her neighbours saw her as an "energetic religious woman" (MC, 4), it becomes evident later on that she is only nominally Catholic. Her self-imposed duty of revenge and the circumstances of the murder reveal that she only adopted the outward forms of Christianity, 11 while she instinctively retained the substance of her native belief. This is hinted at in the story by the description of her character as a "primitive woman" of "instinctive serenity", who feels "entirely contented" (MC, 3 ) despite poverty and the precarious conditions of her life.

When she discovers that Maria Rosa and her husband are lovers, she wants to die at first, "but not until she had cut the throats of her man and that girl who were laughing and kissing under the cornstalks." (MC, 6). As she knows who is her enemy, she feels it is her duty to avenge herself on Maria Rosa, since the pagan code demands revenge which has the function of ritual cleasing - it permits even blood sacrifice, if necessary, to restore the order of things.12 Here we see that the basic pattern of her culture remains intrinsically unaltered, which is further proved when after the murder she does not feel guilty, on the contrary, she experiences an inner repose and a conviction that her world has assumed its former balance. After feeding the baby, she sits motionless and again entirely contented, hugging the child and listening to her husband's breathing:

B Bee HENDRICK, G. Katherine Anne Porter. New York. Twayne, 1965 p. 30.

9 Juan had been sayed from death by his chlef Glvens. who bought him out from prison. He was to be put to desth because he had deserted the army.

10 PORTER. K. A. Tho Collected Stories of Katherine Anne Porter. New York. Nex American Library, 1970 . p. A. All references and quotations referring to Marla Concepclon and Haclenda will be taken from this edition. Quotations referring to A Curtain of Green and Clytte, will be taken from WELTY. E. A Curtain of Green $\&$ other stories. New York, Harcourt Brace, 1969. 289 p. Quotations referrine to Asphodel wIII be taken from WELTY, E. Selected Staries of Eudora Welty. Ner York. The Madern Library, 1966. 214. p. The titles of the stories rill be citcd in abbrevlated form lollowed by page numbers. The following abbrevlations will be used: Marla Concepción (MC: Haclenda (H); A Curtaln of Grcen (CO); Clstie (C); Asphodel (A.

11 Maria Concepcion went to ehurch regulary, elalmed that she did not believe in witcheraft, and insisted in cetting marred in the church. When Juan left her, she llehted "cnndles belore the saints. kneeing with her arms spread in the form of a cross for hours ut a tlme. and recelving holy communion every month... "See PORTER, The Colleted storics..., p. 9.

12 According to M. ELIADE, to primitlve poople the sacriflce has a proper end "to restore the primordial unity... The sacrificer's cffort to re-establish the primordial unity. that is, to restore the whole which preceded the Creation. is a rery Important characteristic of the Indian spirit with its thlrst for primordial unlty..." (Bee ELIADE, $M$. The Myth of the Eternal Return: or, Cosmos and History, Princeton, Princeton Unlversity Press, 1974, p. 78). 
Maria Concepción could hear Juan's breathing. The sound vapored from the low doorway, calmy; the house seemed to be resting after a burdensome day. She breathed, too, very slowly and quietly, each inspiration saturating with repose. The child's light, faint breath was a mere shadowy moth of sound in the silver air. The night, the earth under her, seemed to swell and recede together with a limitless, unhurried, beningn breathing. She drooped and closed her eyes, feeling the slow rise and fall within her own body. She did not know what it was, but it eased her all through. Even as she was falling asleep, head bowed over the child, she was still aware of a strange, wakeful happiness. (MC, 21)

The conjunction of contrasting images such as day/night, rise/fall and sleep/wakefulness represent the mingling of contraries, the antithetical forces blending into synthesis or unity, which suggests the restoration of the natural liferhythms.

There is evidence in the story that in the process of acculturation Maria Concepción has developed a dual set of values, but that she merely imitates the forms of Christianity she is supposed to have assimilated, since in a moment of crisis she rejects the Christian code which demands the turning of the other cheek. There are instances in the story when we notice her vacillation between the established values of the present and her primitive consciousness of the past. Her confused psy. chological state is objectified through her stumbling and running over the fields, instead of "taking the accustomed road" (MC, 13) to the market, after Maria Rosa and Juan have returned from the army. The realization of her murderous thoughts were at first shocking to her; the opposing values clash together violently, which is expressed in her intense suffering before her decision to kill:

She sat down quietly under a sheltering thorny bush and gave herself over to her long devouring sorrow. The thing which had for so long squeezed her whole body into a tight dumb knot of suffering suddenly broke with shocking violence. She jerked with the involuntary recoil of one who receives a violent blow, and the sweat poured from her skin as if the wounds of her whole life were shedding their salt ichor. (MC, 13) 
However, it is her primitive consciousness that dictates her what to do, and after having made up her mind, she carries forward her determination, feeling no guilt or remorse.

The fact that the violent deed is not described in the story is indicative that the act in itself is not important according to the primitive code; what is important is the meaning and the implications of the act. Since she kills to preserve the family intact, her deed is accepted as right by the whole Indian community. When the police arrives at Maria Rosa's house to investigate the murder, nobody accuses her, although they are all aware that she had murdered her husband's mistress. Looking around

Maria Concepción suddenly felt herself guarded, surrounded, upborne by her faithful friends. They were around her, speaking for her, defending her, the forces of life were ranged invincibly with her against the beaten dead. (MC, 20)

This suggests the participation of the whole Indian community in the ritual blood sacrifice in order to re-establish peace and happiness. This practice is an expression of their primitive consciousness, which lies submerged in their unconscious, suppressed by a superimposed alien culture, but it is bound to come to surface again in moments of crisis in which a choice is made imperative.

\subsection{The New Order: A Wasteland of Violence and Death in Hacienda.}

R.B. West asserts that what is rendered in Hacienda is "a complicated wasteland inhabited by a new order that has rejected the old values, but has discovered no common basis for the new." 13 As he puts it, the result is a comedy of no manners; in fact, the owners of the pulque hacienda, the decadent Mexican aristocrat Don Genaro (a caricature of the idealized Spanish Don) and his wife doña Julia are Mexican copies of the Lost Generation - they live in a world of appearances, which is empty and loveless, acting out their futile, pointless life roles.

The absurdity of the situation is heightened by the theme of appearance/reality - the distorted reality of the place is further distorted in the film. This evokes Plato's theory of the two contrastive worlds - the ideal and the real; the world of the senses being an imperfect copy of the world of ideas. Furthermore Plato claims that the work of the artist falsifies

13 see WEST, R.B. Katherine Anne Porter. Minncapolis, University of Minnessota Press, 1968. p. 9. 
reality twice, since it attempts to imitate the world of the senses which is already a falsification of the ideal reality.

Keeping Plato's concept of art in mind, we become aware of the profound irony implied, when the narrator of the story reports that the Russians, with the cooperation of the Mexican government, were making a film to show how "the revolution of blessed memory" ( $H, 135)$ had swept away the hacienda system when, in fact, nothing at all had changed. She states that Andreyev, one of the three Russian moving-picture men, thinks that the whole thing is "almost too good to be true" $(H, 142)$. We perceive more irony when he tells her that

Pulque making had not changed from the beginning, since the time the first Indian set up a rawidhe vat to ferment the liquor and pierced and hollowed the first gourd to draw with his mouth the juice from the heart of the maguey. Nothing had happened since, nothing could happen. Apparently there was no better way to make pulque. $(H, 142)$

We perceive the truth of the affirmation that nothing has changed to improve the life of the peon since the days of the glorious revolution, but we also realize that to say that nothing has changed since the beginning when the Indian discovered pulque is a great lie - the situation of the dehumanized, oppressed peon is, in fact, very different from that of his ancestor, the primitive Indian who owned the land before the conquistadores came.

The greatest irony is that Velarde "the most powerful and successful revolutionist in Mexico "was the owner of "two pulque haciendas which had fallen to his share when the great repartition of land had taken place", furnishing milk to charitable institutions and "getting just twice the prices for them that any other dairy farm would have asked." $(H$, 156)

This suggests that history repeats itself, since it reminds us of an earlier time, when the mission establishments were replaced by the hacienda system, and great areas of land, expropriated from the missions were distributed among the important landholders. The hacienda system was premised upon the concept of peon labour, recruiting wild Indians and neophytes $^{14}$ to work as vaqueros or houseservants. Some-

The neophstes were those Indians, who had already lived and worked in the mission establishments. It is important to mention that in time the purpose of the religicus orders to catequize the Indians became corrupted and tristed. Thes began to enslave the Indians, adopting the forced labour system in order to accomplish their far-fiuns enterprises. Brutal treatment of the Indians, explains the persistence of an ugly racial arrogance. The padres were opposed to educating the Indians for the same reasons that the Southern slareholders were opposed to educating the Negro, since Ignorant people are more easily subjected. 
times the newly-rich hacendados simply kidnapped Indians to work for them. Although slavery had been abolished in Mexico in 1829 , peonage continued to be practiced, which was in many ways no better than slavery. The practice of removing the Indians from their natural habitat, forcing them to live at first at the missions and then at the great haciendas resulted in a complete disruption of the Indian culture.

There are hints in Hacienda that the Indians, unlike the Negroes of the Southern states, resisted slavery with pride and defiance, but that they were violently subdued by the conquistadores, who determined either to subject or to exterminate them. Their history is written in blood, therefore the land seems to be cursed and a death-expectancy looms over the landscape:

The camera had caught and fixed in moments of violence and senseless excitement, of cruel living and tortured death, the almost ecstatic death-expectancy which is in the air of Mexico... In the Indian the love of death had become a habit of the spirit. It had smoothed out and polished the faces to a repose so absolute it seemed studied, though studied for so long it was now held without effort; and in them all was a common memory of defeat. The pride of their bodily posture was the mere outward shade of passive, profound resistance; the lifted arrogant features were a mockery of the servants who lived within. $(\mathrm{H}, 143)$

The fact that the hacienda had formerly been a mission establishment "a monastery, a walled fortress" with the "main corral", "the patios", "the gardens", "the balconies" and "ruins of the old monastery stone bath" ( $H, 151,166)$ is significant, bringing back memories from the past when the hacienda system came into being. This indicates that not since the beginning of the Indian culture, but only after the advent of the mission establishments, the setting has remained exactly the same, as well as the basic situation; however while things have not been altered, in the long run the human element has changed - the system has not only disrupted the Indian culture, but also degraded the white man. Don Genaro and doña Julia are portrayed as less than human, almost caricatures, living in a world of illusion which is ultimately undistinguishable from the film that is being made. The utmost irony in the story is that the peon Justino, who has an important role in the drama of illusion, in real life imitates the illusory world of the film - this kind of confusion of values 
results in tragic violence since it implies in a complete loss of identity. According to H.J. Mooney the white people assembled at the hacienda are responsible for the peon's destruction. "They represent the corruption on the one hand, and the confusion on the other, of modern social and political history; and it is in this sense that they are directly connected with the pzon, who, we are led to believe, would never have murdered his sister had he not been caught in their midst."15

Much of the story revolves around the various reactions to the tragedy at the hacienda that day. Nobody seems to be concerned about the fate of the peon - the concern of those people assembled at the hacienda is with the film; they need Justino because he has an important role in it. The death of Justino's sister is not heeded by anybody; each individual pursues only his own selfish interests, which denotes insensivity, lack of humanity and cruelty. In Hacienda the central theme is the forces of death conquering over life, in a world of perverted ideals and false values.

Death is a recurrent motif in the story - connected with the story's basic integrated symbol, which fuses and makes meaningful all facts - the pulque or "corpse-white liquor" $(H, 168)$ which is at the core of the oppressive social system of the hacienda. The stench of pulque can be equated with the odour of death that infects the air, symbolizing the spiritual and moral corruption of society itself. The narrator of the story understands the very nature of degradation when the smell of the stinking liquor mixed with dona Julia's perfume penetrated her nostrils "sour, stale, like rotting milk and blood" ( $H, 161)$. In the story the liquor from the lifegiving plant becomes a metaphor of death. The flies drowning in the nauseating liquor metaphorically represent the victimized Indians, who get drunk to forget their misery, while the hacendado transforms pulque into money which generates still more corruption:

The white flood of pulque flowed without pause; all over Mexico the Indians would drink the corpsewhite liquor, swallow forgetfulness and ease by the riverful, and the money would flow silver-white into the government treasury; don Genaro and his fellow-hacendados would fret and curse, the Agrarians would raid, and ambitious politicians in the capital would be stealing right and left enough to buy such haciendas for themselves. It was all arranged. $(\mathrm{H}, 168)$ 
Here K. A. Porter suggests that there is no possibility of regeneration for such a wasteland, where corruption and degradation has become a vicious circle.

\section{EUDORA WELTY}

\subsection{Death as Revelation of the Paradoxical Nature of Life in A Curtain of Green}

In The Crown, one of $\mathrm{D}$. $\mathrm{H}$. Lawrence's most important philosophical essays, the general role of death is suggested: "The near touch of death may be a release into life; if only it will break the egoistic will, and release that other flaw from the soul."': In other essays, Lawrence discussed on the ability of death to bring about resolution, inner peace and harmony. He stresses the importance of the yielding of the will into acceptance, claiming that an attempt to avoid the harsh realities of life is a self-destructive act. We must embrace life with all its contradictory aspects - the ultimate caprice being death - since it is as much a part of the natural cycle as life. Death is the natural consequence of life; it is half of the rhythm of life - if you deny one, you are denying the other.

Mrs. Larkin in A Curtain of Green is a strong-willed female, who in denying death, also denies life. The story begins showing the wilful isolation of Mrs. Larkin, who suffers from a deep psychological wound, inflicted upon her on the occasion of the violent loss of her husband, who was accidentally killed by a tree that crushed him to death.

The death of her husband forced upon her a condition of sterility, therefore, she retreats into her garden behind the 'curtain of green', so as to hide from everyday reality which seems unbearable to her. She starts growing plants, yet "she seemed not to seek for order, but to allow an overflowering, as if she consciously ventured forever a little farther, a little deeper, into her life in the garden". (CG, 211)

The lack of order, not taking into account harmony or proportion, suggests a regression to chaos, and this dissolution of forms metaphorically denotes loss of identity. The loss of identity motif is further reinforced by the author through her insistence that Mrs. Larkin was almost invisible in the midst of the greenness of her garden:

She worked without stopping, almost invisibly, submerged all day among the thick, irregular, sloping beds of plants... To the neighbours gazing

16 LAWRENCE. D. II. The Crcwn. In: ROBERTS, W. \& MOORE. If. T. eds. Phoenix II: Uncollected, Unpublished and other Prose Works by D. II. Laxrence. London. Helnemann, 1968. p. 399. 
down from their upstairs windows it had the appearance of a sort of jungle, in which the slight, heedless form of its owner daily lost itself. (CG, 210,212 )

At the climax of the story, we see Mrs. Larkin possessed by a terrible lust for destruction, when she raises the hoe to kill her Negro gardener, whom she has noticed closely for the first time, perceiving "the way he looked a child." (CG, 215) This makes her painfully aware of her "impossible dream" (CG, 315) - of her wish to become a mother. However, she is prevented from committing such a violent action by the sudden rainfall that makes her come back to reality. Immediately she starts reflecting over the mystery of life and death - now she understands that life and death are arbitrarily given and taken. Although she does not find any ra. tional answer for human action, she tries to analyse the paradoxical nature of life:

... so helpless was she, too helpless to defy the workings of accident, of life and death, of unaccountability... Life and death, she thought, gripping the heavy hoe, life and death, which now meant nothing to her but which she was compelled to wield with both her hands... (CG, 216-7)

The rain slowly restores her to life again, she abandons herself to it, experiencing release - she submits to the forces of life and, therefore, she is ready to re-assume her identity:

In the light from the rain, different from the sunlight everything appeared to gleam unreflecting from within itself in its quiet arcade of identity. (CG, 217)

The fact that she lies down, letting the rain pour over her face and body suggests baptism.

Being confronted with the idea of death, since she almost killed the Negro boy driven by a savage impulse, Mrs. Larkin is shocked into recognition and she emerges from the experience with a fuller sense of life. The ritual confrontation with death is fused with baptism, which according to M. Eliade is "equivalent to the ritual death of the old man followed by a new birth"," In accepting death, which becomes clear in

17 ELLADE, p. 59. 
her surrender to baptism, there is a possibility for Mrs. Larkin of renewal of life, since she has willingly accepted the paradoxical nature of universe.

\subsection{Death as an Escape from Death-in-Life in Clytie.}

In Clytie, Eudora Welty presents a world of psychological violence, pain and mystery, full of puzzling gaps and discrepancies, populated by people who try to preserve cherished values and identities belonging to the past within the walls of their ruined mansions, striving desperately to affirm their code despite the times have changed.

In this story the author probes the underlying causes of Clytie's mental disorder and shows her as a victim of her family's psychotic isolation; because of her simple-mindedness the subdues entirely to her older sister Octavia, whose ideas of social stratification condemn her to live in seclusion, since she thinks it is not proper for Clytie to mix with the common folk of the village.

Although Octavia is aware of change and of their own ruin, she indulges in a senseless pride, which takes the form of insistence on priviledge and prerogative. Because she feels superior, she isolates herself and her family within the decayed mansion, which is an appropriate metaphor for the abnormal psychological states of the characters. In preventing contact with life, she begins to destroy life and death creeps into the house. Octavia is unable to face the present situation, and because she has no courage to face the death of the old way of life and values, she decries her own death in life. This failure to choose life is a kind of psychological violence, which cripples and wastes away the mind and the body, setting in a degeneration process. This explains why all the characters of the story present some abnormality, either physical or psychological. There is Clytie herself, who lost her sense of identity living in the midst of the lacerating self-destructiveness of her family; there is her schizophrenic sister Octavia, her alcoholic brother Gerald, and her apopletic father, who is paralyzed and blind, the very prototype of the living-dead. Besides, we are also informed of the tragic death of Clytie's brother Henry, who shot himself firing a bullet in his head.

In her over-assertive way, Octavia resembles Faulkner's Emily Grierson, who also confuses time and place. She threatens to kill everybody who dares to cross her ${ }^{18}$, and she always uses her sister Clytie as an instrument to transmit her

18 This suggestes the self-sufficiency and tho exaggerated pride of the ante-bellum Southerner, who boasted he would kill whoever dared to cross him. See CASH, p. 63.

Letras, Curitiba (32) $39-59-1983$ - UFPR 
messages. Although Clytie had told the old lady next door that she liked the rosebush that had been planted near their fence, after Octavia's disapproval she came out of the house screaming:

My sister Octavia says you take that rosebush up! My sister Octavia says you take that rosebush up and move it away from our fence! If you don't I'll kill you! You take it away! (C, 170)

Here we can see that she probably lost her identity, trying to imitate the behaviour of her sister Octavia; she is suffocated under the domination of her sister, who treats her as a servant and an errand-boy But this is not the only violence Clytie suffers, in her family she finds no warmth or love - all this makes her recoil into a dream world, which starts to co-exist with the real world. In her inner world, Clytie creates a view of herself that does not correspond to reality ; the impossibility to reconcile both worlds leads to her complete destruction.

After her frustrated attempt to establish some contact with a human being, by touching the face of the barber only to be rejected in fear, she runs out the house at her sister's command to fetch rain-water to shave her father. Seeing her face reflected in the water, she understands "it was the face she had been looking for, and from which she had been separated". (C, 177) Not only is she horrified by what she sees an ugly, contracting and suffering face - but she is also shocked into an awareness that life has distorted her vision of herself. She cannot endure the disparity between what is and what ought to be: at that moment she realizes her complete aloneness, she poignantly feels the separateness between human beings. She decides that only death and oblivion can rescue her from her complete isolation:

Clytie did the only thing she could think of to do. She bent her angular body further, and thrust her head into the barrel under the water, through its glittering surface into the kind, featureless depth, and held it there. (C, 178)

The image of drowning has biblical overtones, suggesting destruction, vengeance, purification and revelation. By rendering death in a grotesque posture, describing Clytie's "poor ladylike black-stockinged legs up-ended and hung apart like a pair of tongs", (C, 178) Eudora Welty exposes the pathos of the situation, evoking the effects of terror and the ludicrous at the same time to make reality more bearable. 
2.3 Puritanism vs. Hedonism: Symbolic Death and Resurrection in Asphodel

In Asphodel, Eudora Welty combines reality, allegory, ritual and myth to produce a fantasy that transcends violence and death in the story. Miss Sabina, the repressive agent of the town, exerts psychological and moral violence when she wielded her power, trying to destroy not only reality, but also the dreams of the townspeople with her invasion of the post-office, which according to the narrative voices of the story "was beyond her domain", where people "might still be apart in a dream". (A, 106) However, Miss Sabina succeeds in violating even their dreams, tearing to pieces all the letters, which represent "the inner part" (A, 108) of personality. This destructive tendency of Miss Sabina that leads to her own death is described in grotesque terms in the story:

She was possessed then, before our eyes, as she could never have been possessed. She raged. She rocked from side to side, she danced. Miss Sabina's arms moved like a harvester's in the field, to destroy all that was in the little room. In her frenzy she tore all the letters to pieces, and even put bits in her mouth and appeared to eat them.

Then she stood still in the little room. She had finished. We had not moved when she lay toppled on the floor, her wig fallen from her head and her face awry like a mask. (A, 108)

Her death is graphically described in monstrous terms in the story. In addition, there are hints which suggest that her husband and her three children died tragically because of her destructive instinct. ${ }^{19} \mathrm{Mr}$. Don McInnis is supposed to have died when she set Asphodel on fire; the girl drowned herself before wedding, and one of the boys shot himself publicly in a state of drunkenness.

However, violence and death is obliterated in the story to lend emphasis to the conflict of opposing values, which constitutes the main theme of the story.

Asphodel is a dramatization of the tension of opposites in allegoric form; the 'uneasy balance between Puritanism

19 Accordine to Carl JUNO "By nursine secret destructire attitudes, a wife can drive her husband, and a mother her chlldren, into llincss, accident, or even death." (See JUNG, C. et alli Man' and His Symbols. London, Aldus Books, 1964. p. 191.) 
and hedonism',20 which is one of the characteristic aspects of the Southern temper, is represented allegorically through two opposing masks: one of order, control and restraint, impersonated by Miss Sabina; and the other of disorder, abandon and sensuality, impersonated by $\mathrm{Mr}$. Don McInnis. While the Appollonian mask stands for the puritanical side, the Dionysian represents the hedonistic tendency, which are constantly at war within the self of the Southerner. In the story this opposition is clearly stated by a reference to the houses which belonged to Miss Sabina and Mr. Don McInnis, which were situated almost "back to back on the ring of the hills, while completely hidden from each other, like reliefs on opposite sides of a vase." (A, 98)

These two contradictory aspects generally constitute counterparts of the same personality, however, in the story the autor presents two distinct characters to represent them, in order to show the impossibility of reconciliation and to dramatize the final victory of one over the other.

Ruth M.F. Klieft'1 has suggested that some stories of E. Welty evoke the spirit of the Dionysian rites of birth and death, as well as fertility rites and folk ceremonies which marked the changes of the seasons. It is also known that while Greek tragedy developed out of the Dionysian rites of life and death, Greek comedy was inspired in the fertility rites. What we have in Asphodel, is a queer mixture of ancient tragedy and comedy, associated with the idea of ritual.

The ceremonial ritual feasting of the three old maids right after Miss Sabina's death, reminds us of the orgiastic rites introduced by Dionysius among the women of Thebes. Their orgiastic mood is expressed in images of idleness and languour:

Now they lay stretched on their sides on the ground, their summer dresses spread out, little smiles forming in their mouths, their eyes halfclosed. Phoebe with a juicy green leaf between her teeth. (A, 109)

The excess of food and drink in their baskets also suggests a Dionysian banquet:

20 W. J. CASH asserts that the past continues to exert a certain pressure on the Southern character and that unique qualities of mind emerge from $1 \mathrm{t}$. One of these qualities is what he calls the 'unesasy balance between Puritanism and hedonism', '. e., a conflict of warring orders which the antebellum way of life tended to reconcile. However, he further explains that this opposition becomes irreconctlable with the disappearance of the old wass of life, becoming, in fact, more accentuated in face of adjustment to a new social system. (See CASH, p. 65-78.)

See KLIEFT, R. M. Eudora Welty. Ner York, Trayne, 1962. p. 65. 
Then the baskets were opened, the cloth was spread with the aromatic ham and chicken, spices and jellies, fresh breads and a cake, peaches, bananas, figs, pomegranates, grapes, and a thin dark bottle of blackberry cordial. (A, 97)

During their ritualistic banquet, the three spinsters reenact the life and death of Miss Sabina and Mr. Don McInnis in the manner of a Greek chorus; they summon up what has happened, speaking either individually or all together. This ritualistic re-enactment of Miss Sabina's life and death, suggests a ceremony of exorcism - the expulsion of her demon,, 2 in order to become liberated from her dominion. The death of Miss Sabina meant for them the end of Appollonian rule, and the possibility of new birth through the resto. ration of the Dionysian order:

Here in the bright sun where the three old maids sat beside their little feast, Miss Sabina's was an old story, closed and complete. (A, 109)

Immediately after the exorcising ritual of Miss Sabina's demon, the three old maids seem to be transported into mythical time, since in their imagination they create a mythical landscape populated by supernatural beings. They have a su. pernatural vision - the ghostly image assumes the shape of Mr. Don McInnis, who appears to them completely naked. They make an identification of the apparition with Dionysius since they associate his image with that of a lion and a goat. $\mathrm{He}$ scems to them "as rude and golden as a lion" and "as naked as an old goat",;3 (A, 109, 110) they see him in bestial shape which he is supposed to have assumed in Greek mythology. Furthermore, soon after they have another vision of a herd of goats chasing them, which suggests "spirits of fertility such as satyrs", 24 which are known to be followers of Dionysius. The identification of Dionysius with the satyr, suggests bestial nature and great lasciviousness, since the satyr is a mythological creature, half-man and half-goat - a creature of great lustfulness.

These mythological allusions whatever subtle, have a great power of suggestiveness, revealing the internal mental

22 According to M. ELIADE, primitive people uscd to hold seasonal festivals, which ssmbolize the end and the beginning of a temporal period. These ceremonles involve the expulsion of demons, diseases or sins, followed by collective orgies, thus restoring. if only momentarily, mythical or primordial time. (Bee ELIADE, p. 51-4).

23 It is sald that Dionysius sometimes assumed "bestial shape, and is associated with the bull. the panther. the llod, the snake. the tiger, the ass, the zoat, and sometimes the dolphin." (see ENCYCLOPAEDIA Britannica. London, 1971, v. 7, p. 46f-7).

24 ENCYCLOPAEDIA Britannica, v. 7, p. 466. 
processes of the three old maias. The vision of Dionysius and his satyrs is a projection of the psychological state of the protagonists. In their asexuality, there is repressed desire for sexual experience, which comes to the surface after the ritualistic exorcising of Miss Sabina's demon - who is the repressive agent of the town.

The mythical overtones of the title of the story are also important. 'Asphodel' in Greek legend is a flower related to the dead and the underworld, often connected with Persephone or Kore, $=$ the young grain-goddess, daughter of Demeter, who was seized by Hades and removed to the underworld. Hades was bidden to send her back to the living on her mother's request, which he was willing to do, but as "she had eaten a pomegranate seed while in the underworld, she could not be completely released. and a compromise was reached by which she spent one third of the year with her husband, and the rest with her mother." phone or Kore, are the leading goddesses in the Eulisinian mysteries, and are associated with Dionysius.

In the story the three spinsters bring 'pomegranates' in their baskets, and later there is a reference to 'seeds' when they hold the fruits upon their palms, which "were transparent in the light, so that the little black seeds showed within." (A, 107)

The mythological hints suggest that Cora can be identified with Persephone or Kore, the divided goddess, who spent two-thirds of her life among the living and one third among the dead. Here we have a suggestion of the divided personality, which can be detected not only in Cora, but in the three of them. Although they take delight in the vision they see, at the same time they feel guilty, being overcome by an awareness of having trespassed the order. The ambivalent feelings of anger indignation and suppressed pleasure, refer to the impossibility of reconciliation of Puritanism and hedonism. The three spinsters are at the same time attracted and repuised by the naked apparition, not knowing whether to stay or to floe:

As if they heard a sound in the vibrant silence they were compelled to tarry in their flight. In a soft little chorus of screams they waited, looking back over their shoulders, with their arms stretched before them. $(A, 109)$

Their fantastic dreams suggest their desire for new birth - a return to the golden days of the Dionysian rule. However,

25 Kore is the Greek word for "maiden"

26 ENCYCLOPAEDLA Britannica, v, 16. p. 1121. 
their retreat into a dream world, cut off completely from the real world beyond time and space, makes us aware of the impossibility of a new birth as such in real life, since when they awaken from their dream it becomes clear that they cannot escape from their Puritan heritage. The story ends in moral ambiguity, offering no final conclusion, but only paradox.

\section{CONCLUSION}

Katherine Anne Porter and Eudora Welty show a great awareness of how life is actually lived in the particular regions which they describe. Although they create worlds recognizably grounded in the real world (whether it is Mexixco or the American South), populated by characters that are products of the place in which they live, their main concern is with human beings and human values. Therefore, they transcend their region and their work acquires universal significance.

Although they write fiction, they reveal an acute historical sense; there are many hints in their stories which suggest that the present life of the characters has to do with the past, which has not ceased to exert its influence.

They seem to advocate that in an ambiguous world, deprived of meaning there is a greater propensity for physical, psychological and moral violence. This is clearly expressed in K.A. Porter's Hacienda, where the oppressive social system not only degrades the peons, but also corrupts the white man. The spiritual isolation of the characters is reflected in the very landsca $=$ in which they move, in which images of violence and death prevail.

In Clytie and Asphodel, Eudora Welty shows that in an incongruous world, where opposing values clash together, the individual is trapped and forced to seek an escape. While Clytie chooses to commit suicide, the three old maids in Asphodel resort to fantasy to make reality more bearable.

Both writers also unveil the nature and fate of the livingdead among us - those static creatures who are unable to accept the presence and necessity of death. They offer us variations on the theme that death is not final, but only a new beginning. If man accepts the ritual of death he can hope for renewal; however, in denying death, he also denies life. They imply that we cannot hope to exclude ourselves from death and corruption; therefore we must find harmony and peace in the acceptance of the contraries of life and death, love and hate, creation and destruction, light and dark, in the polarity and balance of these forces rather than in the resistance to them, which leads to death alone. 


\section{RESUMIO}

Este estudo visa elucidar as razões da prevalēncia da violència na ficçāo dos escritores sulistas dos Estados Unidos. Enquanto K. A. Porter enfoca a violência como sendo um traço caracteristico do temperamento do sulista, que se originou na época da formaçāo da fronteira, Eudora Welty apresenta variaçōes sobre o tema de isolamento espiritual em seus contos, que está diretamente relacionado com as cosmovisōes conflitantes dos anos quarenta: a confusāo gerada pela discrepância existente entre os ideais do passado mitico da sociedade sulista e o mundo real do sul resulta $\mathrm{cm}$ violència. Tensōes semeihantes àquelas da região Sul são evocadas por $K$. $\Lambda$. Porter em seus contos sobre o México. As diversas conotaçōes de morte, lanto reais como simbólicas, também sāo analisadas neste estudo, mostran. do que a recorrência do notivo da morte se relaciona com as preocupaçōes metafisicas do sulista.

\section{BIBLIOGRAPHICAL REFERENCES}

1. CASH, W.J. The Mind of the South. Harmondsworth, Penguin, 1971. $456 \mathrm{p}$.

2. ELIADE, M. The Myth of the Eternal Return: or. Cosmos and His. tory. Princeton, Princeton University Press, 1974. $195 \mathrm{p}$.

3. ENCYCLOPAEDIA Britannica. London, 1971. v. 7, 16

4. HENDRICK, G. Katherine Anne Porter. New York, Twayne, 1965. $176 \mathrm{p}$.

5. HOFFMANN, FJ. The Art of Southern Fiction: A Study of Some Modern Novelists. Carbondale, Southern Illinois University Press, 1968. $198 \mathrm{p}$.

6. JUNG, C. et alii. Man and His Symbols. London, Aldus Books, 1964. $320 \mathrm{p}$.

7. KLIEFT, R. M. Eudora Welty. New York, Twayne, 1962. 203 p.

8. MOONEY, H. J. The Fiction and Criticism of K. A. Porter. Pittsburgh, University of Pittsburgh Press, 1962. $66 \mathrm{p}$.

9. PORTER, K. A. The Collected Essays and Occasional Writings of K. A. Porter. New York, Dell, 1973. 496 p.

10. The Collected Stories of Katherine Anne Porter. New York, New American Library, 1970. $495 \mathrm{p}$.

11. RANSOM, J. C. ed. I'll Take My Stand. New York, Harpers, 1962.

12. ROBERTS, W. \& MOORE, H. T. eds. Phoenix II: Uncollected, Unpublished and Other Prose Works by D. H. Lawrence. London, Heinemann, 1968. $640 \mathrm{p}$. 
13. WALSH, T. F. Xochitl: Katherine Anne Porter's Changing Goddess. American Literature, 52 (2): 183-93, 1980.

14. WELTY, E. A Curtain of Green and Other Stories. New York, Harcourt Brace, 1969. 289 p.

15. Selected Stories of Eudora Welty. New York, The Modern Library, 1966. 214 p.

16. WEST, R. B. Katherine Anne Porter. Minneapolis, University of Minnessota Press, 1968. $48 \mathrm{p}$. 